boarding school due to the intermediate variant strain of influenza $B$ virus. Paired sera from six students (aged 11-15) with infection proved by virus isolation and/or a fourfold rise in antibody level (haemagglutination inhibition or complement fixation test) were subsequently tested by the fluorescent antibody technique for class-specific fluorescent antibody to the three influenza B strains (old influenza B virus and the two recent variants, the intermediate strain and strain $\mathrm{B} / \mathrm{HK} / 5 / 72$ ). Virus-infected cell preparations on glass slides and standard immunofluorescent techniques were used essentially as described previously. ${ }^{3}$ Preparations were examined under a Tiyoda R1 tr microscope, using a $2 \mathrm{~mm}$ OX1 exciter filter and an $805 \mathrm{Q}$ barrier filter with mencury vapour illumination. A significant feature of the responses detected is that the IgG titre was rather similar against all three strains; any differences in the titres were fourfold or less (table I). Preliminary work done with paired sera from an outbreak due to influenza $\mathrm{B} / \mathrm{HK} / 5 / 72$ virus gave results of a similar nature. This points to the possibility that infection due to one strain could result in some immunity to all three.

TABLE I-IgG Fluorescent Antibodv Response to In-
fluenza B in Children Aged 11-15 Years Infected with the Intermediate Strain of Influenza B Virus

\begin{tabular}{|c|c|c|c|}
\hline \multirow[b]{2}{*}{ Patient } & \multicolumn{3}{|c|}{ Virus Strain } \\
\hline & $\begin{array}{l}\text { Old Influ- } \\
\text { enza } B^{*}\end{array}$ & $\begin{array}{c}\text { Intermediate } \\
\text { Influenza B }\end{array}$ & $\begin{array}{c}\text { Influenza } \\
\mathrm{B} / \mathrm{HK} / 5 / 72\end{array}$ \\
\hline $\begin{array}{l}1 \\
2 \\
3 \\
4 \\
5 \\
6\end{array}$ & $\begin{array}{c}7.5 / 160 \dagger \\
\leqslant 5 / 320 \\
7.5 / 30 \\
15 / 240 \\
5 / 120 \\
\leqslant 5 / 120\end{array}$ & $\begin{array}{r}5 / 240 \\
<5 / 320 \\
<5 / 60 \\
10 / 960 \\
15 / 160 \\
<5 / 80\end{array}$ & $\begin{array}{l}<5 / 60 \\
<5 / 80 \\
<5 / 30 \\
<5 / 640 \\
5 / 80 \\
<5 / 40\end{array}$ \\
\hline
\end{tabular}

*B/England/32/71.

+Acute/convalescent serum specimens (taken 18 days apart).

TABLE II-IgG Fluorescent Antibodies to Influenza $B$ Virus (Old Strain) in Manchester Sera, 1971

$\begin{array}{cc}\text { Age (years) } & \text { Percentage with Antibody* } \\ <6 / 12 & 57 \\ \geqslant 6 / 12 & 21 \\ 1-4 & 33 \\ 5-10 & 34 \\ 11-20 & 70 \\ 21-35 & 97 \\ >35 & 100 \\ & 89\end{array}$

*Sera screened at $1 / 10$.

Fluorescent antibody studies done in 1971 on a random collection of Manchester sera ${ }^{4}$ are of interest in this context. If the presence of IgG fluorescent antibody to influenza B virus is taken as an index of immunity to influenza $B$, the results (table II) indicate that immunity should be maximal in the adult age groups, whereas a proportion of individuals less than 20 years of age should be susceptible to influenza B infection. The known epidemiological features of the disease support this hypothesis in that influenza $\mathbf{B}$ infections do predominantly affect the younger age groups. The epidemiological behaviour of infections due to the two new variant strains, which last winter left older age groups relatively unaffected, could also, on the basis of these figures, point to the presence of crossimmunity between the three strains of influenza $B$, as postulated above. Studies are now under way to assess further the usefulness of the fluorescent antibody technique in predicting immunity or susceptibility to the various strains of influenza $A$ and $B$ by determining the fluorescent antibody titres to the different influenza strains in selected sera.-We are, etc.,

L. M. DE SILVA

P. R. MORTIMER

Public Health Laboratory,

D. P. CASEMORE

General Hospital,
Middlesbrough

1 British Medical fournal, 1974, 2, 511.
2 British Medical fournal, 1974, 2, 620.

de Silva, L. M., et al., fournal of Hygiene, 1973.

Tobin, J. O'H., and de Silva, L. M. Unpublished observations.

\section{Vaccination against Whooping Cough}

SIR,-Your leading article (31 August, p. 539) comprehensively analysed the difficulties in assessing vaccination against whooping cough. There may perhaps be some over emphasis at the beginning on laboratory methods of assessing the effectiveness of vaccination against infectious disease. Unless the specific protective property conferred by the vaccine against the particular infectious disease can be isolated and accurately assayed laboratory estimations offer only presumptive evidence.

The only valid assessment of routine immunization is the effect it produces in routine use. This, as you rightly point out, is exceptionally difficult to determine because the epidemiology of the disease is being modified simultaneously by many factorssocial, nutritional, cultural, and therapeutic, to name only some-as well as by the immunization procedure itself. One of the more striking changes in the epidemiology of pertussis is the raising of the age of attack, and this has certainly contributed considerably to the reduction in death rate. There is evidence to suggest that routine vaccination has been an important factor here.

Laboratory tests have another disadvantage in that they imply that the production of absolute protection is necessary for the vaccine to succeed in practice. When a vaccine is used widely less than $100 \%$ effectiveness may well achieve the desired result. The production of undesirable side effects is not only unfortunate for the children who exhibit them but is also of importance in reducing acceptability. It may be more important to produce a vaccine which is acceptable but less effective than a vaccine which is $100 \%$ effective but non-acceptable to some parents because of side effects. The use of a two-dose schedule of the absorbed vaccine at a reduced strength could be as effective as a more frequent administration at a higher dosage, especially if it achieved a wider use because of a higher acceptability.-I am, etc.,

University of Otago,

J. S. DODGE

Dunedin,

New Zealand

\section{Respiratory Distress Syndrome in the Newborn}

SIR,-Your leading article on the present more hopeful position for the premature infant with respiratory distress syndrome (R.D.S.) (23 November, p. 428) rightly emphasizes the results that can be achieved with modern intensive care. It also raises wider issues concerning the care of the sick newborn.

Your suggestion that "each N.H.S. area should surely come to an agreement that women in premature labour should be transferred for delivery to a unit fully equipped to deal with R.D.S. of all degrees of severity; infants with R.D.S. do not travel well" is a sensible one, and if one could be assured that not too many of these infants would be born in the ambulance en route, possibly even a practical one. It would ensure that infants not ill enough to require intensive care could return with their mothers, whereas those requiring it would have immediate intensive care available. On the other hand, your suggestion that "what is required is a technique which can be set up quickly and easily in the special care unit of any maternity hospital" may be a hopeful ideal for the future but at present is probably no more than pie in the sky.

At our current state of knowledge, treatment of severe R.D.S. still demands, as do other neonatal illnesses, the provision of medical, nursing, and laboratory vigilance of a high order, available at all times of the day and night. In addition, trained resident staff have to be available at all times to collect infants in distress in outlying hospitals. Infants with R.D.S. may not travel well, but with expert supervision en route they do at least seem to arrive safely.

Results from our own neonatal intensive care unit, and others similar, fully justify the efforts expended. It is surely unrealistic, however, to suppose that a service of this order can exist, or indeed need exist, wherever infants are born, and centralization deserves the highest priority at this time of reorganization of the Health Service.

Recent developments, such as the introduction of continuous positive airways pressure (C.P.A.P.) and the exposure to acute neonatal paediatrics which most junior staff now receive, mean that many infants can be satisfactorily managed in local hospitals. This is to be encouraged. It reinforces the mother-baby link and will improve the overall standards of practice. However, there is no doubt that some infants are too sick to be managed anywhere other than at a regional centre, and it is in their best interests to be transferred as early as possible. The diffioulty, which frequently arises, is how to decide which infant should be transferred.

Professor K. W. Cross ${ }^{1}$ has highlighted the dilemma of oxygen therapy in the newborn and pointed out that avoidance of oxygen damage to the eyes may have resulted in many infant deaths from hypoxia. The crucial deciding factor in the management of severe R.D.S. is probably whether or not the hospital concerned can provide an immediate service for blood gas monitoring throughout the 24 hours and has the necessary trained staff to deal with life-threatening emergencies such as pneumothorax, which so of ten occur.

The indications for transfer of an infant to a central unit thus appear to be threefold: (a) the need to ventilate the infant because of the severity of its disease or apnoeic attacks, (b) inability to manage the infant on C.P.A.P., or (c) lack of facilities for round-the-clock monitoring of arterial oxygen in babies who need it. If such a policy were adopted on a regional basis only a small proportion of infants with respiratory distress syndrome would need to leave their mothers and the specialized units would be 